\title{
Environmental Sustainability: A 30-Year Progress Assessment in Portugal
}

\author{
Rita Cravo ${ }^{1}$, José Guerreiro ${ }^{*}$ \\ ${ }^{1}$ Faculdade de Ciências da Universidade de Lisboa, Lisboa, Portugal \\ ${ }^{2}$ MARE-Marine and Environmental Sciences Centre, Faculdade de Ciências da Universidade de Lisboa, Lisboa, Portugal \\ Email: *jasilva@fc.ul.pt
}

How to cite this paper: Cravo, R. and Guerreiro, J. (2019) Environmental Sustainability: A 30-Year Progress Assessment in Portugal. Journal of Environmental Protection, 10, 1507-1535.

https://doi.org/10.4236/jep.2019.1011090

Received: October 17, 2019

Accepted: November 17, 2019

Published: November 20, 2019

Copyright $\odot 2019$ by author(s) and Scientific Research Publishing Inc. This work is licensed under the Creative Commons Attribution International License (CC BY 4.0).

http://creativecommons.org/licenses/by/4.0/ (c) (i) Open Access

\begin{abstract}
Sustainable development is a common goal for all countries since the concept was adopted at the 1992 Rio Conference. European Union (EU) became a world leader in most of indicators despite successive enlargement of country members with newcomers often facing basic environmental problems. In 1986, Portugal became a member of the European Economic Community (EEC), and immediately began to reflect its environmental policies. Over the last 30 years, the support of EU funds and the implementation of environmental public policies in Portugal, have been essential for the country's sustainable development. As a result, Portugal's standards started to be closer to those of the EU and, in some cases even exceeded it. The present article addresses, for the first time, a long series of 30 years (1987-2017), in a retrospective analysis of a set of indicators, in order to characterize the evolution of Portugal's environmental sustainability, its relationship to the national public policies, and in the context of the EU. The progress of the indicators towards specific environmental sustainability targets is also evaluated. Moreover, a set of key indicators that also evaluate the goals of the 2030 Agenda for Sustainable Development are identified. The results show that the evolution of Portugal's environmental sustainability in the last 30 years was remarkable. The water standards, air quality, urban waste, and energy sectors showed high improvement. However, the evolution in the sectors such as land use, and environmental risks, particularly forest fires, were negative. On the other hand, for some indicators, such as renewable energies or bathing water quality, Portugal performed better than the EU-28. Environmental performance shows the positive influence of EU environment policies and structural support, changing dramatically the quality of the environment in Portugal, from a negative situation to a success case study in a generation period.
\end{abstract}

\section{Keywords}

Environmental Sustainability, Indicators, Sustainable Development Goals, 
2030 Agenda

\section{Introduction}

The report "Our Common Future" [1], prepared under the aegis of the World Commission on Environment and Development and coordinated by Gro Harlem Brundtland, defined a concept of sustainable development. The Brundtland Report became the theoretical basis of the 1992 United Nations (UN) Conference on Environment and Development (Eco-92-Rio de Janeiro Conference), setting an agenda for the century regarding sustainability: Agenda 21.

Although it was a theoretical concept, Agenda 21 itself, set as an objective in its Chapter 40, “... to develop sustainable development indicators that serve as a solid basis for decision-making at all levels and contribute to self-regulated sustainability of integrated environmental and development systems. Countries at the national level and governmental and non-governmental organizations at the international level should develop the concept of sustainable development indicators in order to identify these indicators" [2]. In December 1992, the United Nations Commission on Sustainable Development (CSD) was created by the UN General Assembly to strengthen the implementation of Agenda 21.

Subsequently, in 1993, further to Eco 92, the baseline indicators for environmental performance review [3] were adopted, following the PSR methodology (Pressure/State/Response). Environmental statistical analysis dealt not only with data on pressures, state and responses, but also with their origins in economic activities. Thus, in the early 1990s, a primitive DPSIR (Driving Forces/Pressures/State/Impacts/Responses) model was developed as a structuring basis for environmental statistics. This methodology described: human activities, pressures, state of the environment, impacts on ecosystems, human health and materials and responses. The well-known Dobris Report, "The General Strategy for Integrated Environmental Assessment at EEA" [4], was developed on this concept, with the European Environment Agency (EEA) now adopting the DPSIR model [5]. The methodology came to be generalized, covering various scales of analysis, from integrated coastal zone management programs to agricultural policies or, at a larger scale, to the country's performance (EEA), becoming a key instrument in the identification of political solutions or the impacts of those solutions [6] [7].

The Organisation for Economic Co-operation and Development (OECD) and EEA models became more and more generalized by developing their set of specific indicators along the path of Agenda 21 recommendations. The first European Sustainable Development Strategy (EU SDS) was adopted at the Göteborg European Council in 2001, known as "A Sustainable Europe for a Better World: A European Strategy for Sustainable Development”.

In 2005, the European Commission approved its sustainable development indicators system including more than 100 indicators in 10 areas, of which 50 cov- 
ered environmental issues [8]. The European Environment Agency [9] reviewed and refined the set of indicators in 2014 by grouping them into 13 core themes (air pollution, biodiversity, climate change, energy, environmental scenarios, fisheries, green economy, household consumption, land, soil, transport, waste and water) in a global set of 137 indicators. The system of indicators has been used in the context of the EU to assess the performance of EU environmental policies expressed in the EU Environmental Action Programs, notably the 5th and 6th Program. Indeed, the role of those indicators supporting the development and evaluation of public policies was already recognized by Smeets and Weterings [10] who considered that environmental indicators served three purposes: 1) to provide information on environmental problems to enable policy makers to gauge its gravity; 2) support the development and prioritization of policies, identifying the key factors of pressure on the environment; and 3) monitoring the effects of policy responses.

The assessment of sustainable development was maintained on a regular basis using the sets of indicators defined up to the transition to the Sustainable Development Goals (SDG). In September 2015, at the United Nations Summit on Sustainable Development in New York, the resolution "Transforming our world: the 2030 Agenda for Sustainable Development" [11] was adopted. This resolution entered into force on the 1st January 2016 [12]. 2030 Agenda is now the new global strategy for sustainable development, consisting of 17 SDGs, broken down into 169 targets [13]. The SDGs replaced the Millennium Development Goals (MDGs) adopted in 2000 which were the guide to development action by 2015. Unlike the MDGs, SDGs set out a wide range of economic, social and environmental objectives for all countries, developed and developing alike [11]. The SDGs offer a universal, broad and ambitious agenda for the three dimensions of sustainable development. In 2016, a list of 241 indicators was adopted, and in March 2017, at the 48th session of the United Nations Statistical Commission (UNSC), some adjustments were made [14]. This new list includes 232 indicators (the total set includes 244 indicators, since some indicators are used to monitor more than one target) [11]. The UNSC has defined for this list annual adjustments and more comprehensive revisions to be made in 2020 and 2025 [14].

At the regional level the EU adopted in May 2017 a document entitled "EU SDG indicator set" developed by Eurostat. This document lists 100 different indicators to monitor EU progress towards SDGs. Of these, 51 are also on the UN list. The EU set of indicators aims to include indicators relevant to the EU for monitoring of SDGs in the context of long-term EU policies.

Portugal became a member of the European Economic Community (now, the $\mathrm{EU}$ ) in 1986, and immediately began to reflect the environmental policies of the EEC. Accordingly, the first Environmental Law was approved in 1987 (Law 11/87). Subsequently, as a result of public policies on the environment and the application of Community funds, a dramatic change in environmental quality in Portugal begins, particularly in the areas of water supply, sanitation and waste 
management, the so-called first generation of environmental policies. Accompanying the EU, the Ministry of Environment and Spatial Planning published in 2000 the first edition of the National Sustainable Development Indicators System SIDS Portugal (SIDS), which was brought up to date in 2007 [15], and launching the National Environment and Sustainable Development. Portugal produced only two biennial reports (2009 and 2011), evaluating its evolution of sustainable development, based on the "traffic light system" methodology. This evaluation was discontinued with the entry into force of the SDGs.

This paper reviews, for the first time, a long series of 30 years (1987-2017), in a retrospective analysis of the indicators of sustainable development, following the concept of ex-post (backward looking) policy evaluations quoted by Maas et al [16]. This case study focuses on the environmental dimension, in relation to national public policies in the context of the EU. The aim is to relate SIDS indicators to SDG indicators.

\section{Methods}

In this section we present the methodology used to evaluate the evolution of environmental sustainability in Portugal from 1987 to 2017. A four-staged approach was defined: 1) Selection of Sustainable Development Indicators; 2) Quantitative Evaluation of the Sustainable Development Indicators from 1987 to 2017; 3) Qualitative Evaluation of the Sustainable Development Indicators; 4) Selection of Indicators for the 2030 Agenda.

\section{Selection of Sustainable Development Indicators}

The selection of the indicator set characterizing the evolution of Sustainable Development in the last 30 years is based on the Portuguese Sustainable Development Indicators System, "SIDS Portugal” [15]. This study reviews data available for the environmental indicators from SIDS Portugal.

The environmental-economic and environmental-social indicators were also considered, such as energy and carbon intensity of the economy, and forest fires. In order to identify and assess the existing data and information on these indicators, we analyzed the annual Portuguese Reports on the State of the Environment from 1987 to 2017 . Table 1 shows the criteria used to select the most appropriate indicators for the study. Table 2 shows the selected indicators.

Table 1. Criteria used for the final indicators selection (Adapted from Cook, et al. [17]).

\section{Criteria used to select indicators}

- Be Similar to SIDS Portugal: The indicator should be as established in SIDS Portugal.

- Adaptability of the indicator: Indicators with different units of measurement and/or methodological approach from those established in SIDS Portugal but, nevertheless, adaptable, should be considered.

- Relevance of the indicator: The indicator should be relevant, useful and adequate for the study, in the context of the environmental sustainability assessment.

- Availability of information: The indicator should have adequate coverage over time (at least 4 years). 
Table 2. Indicators selected and Targets used in the Qualitative Evaluation of Sustainable Development Indicators. Source of data: [18] [19] [20] [21]. Note: NA: Not Applicable.

\begin{tabular}{|c|c|c|}
\hline Indicators & Targets & $\begin{array}{l}\text { Targets } \\
\text { Source }\end{array}$ \\
\hline \multicolumn{3}{|l|}{ Water } \\
\hline $\begin{array}{l}\text { Population served with Water } \\
\text { Supply Systems }\end{array}$ & $\begin{array}{l}\text { To serve } 95 \% \text { of the total population of Portugal } \\
\text { with public water supply systems. }\end{array}$ & PEAASAR II ${ }^{1}$ \\
\hline $\begin{array}{l}\text { Population served by Wastewater } \\
\text { Drainage and Treatment Systems }\end{array}$ & $\begin{array}{l}\text { To serve } 90 \% \text { of the total population of Portugal } \\
\text { with public drainage and urban wastewater } \\
\text { treatment systems. }\end{array}$ & PEAASAR II \\
\hline Water Consumption & No target set & NA \\
\hline Drinking-water Quality & $\begin{array}{l}\text { Percentage of the total number of treated water } \\
\text { analyses which are in conformity with the } \\
\text { legislation: Reference value } \geq 99 \% \text {. }\end{array}$ & PEAASAR II \\
\hline Bathing Water Quality & No target set & NA \\
\hline \multicolumn{3}{|l|}{ Air Quality } \\
\hline Greenhouse Gas Emissions & $\begin{array}{l}\text { To limit GHG emissions growth to } 27 \% \\
\text { compared to } 1990 \text {, in the } 2008-2012 \text { period. }\end{array}$ & $\mathrm{ENDS}^{2}$ \\
\hline Air Temperature & No target set & NA \\
\hline Air Quality & No target set & NA \\
\hline \multicolumn{3}{|l|}{ Land Use } \\
\hline Land Use and Land Cover & No target set & NA \\
\hline \multicolumn{3}{|l|}{ Nature and Biodiversity } \\
\hline \multicolumn{3}{|l|}{ Conservation } \\
\hline $\begin{array}{l}\text { Classified Areas for Nature and } \\
\text { Biodiversity Conservation }\end{array}$ & $\begin{array}{l}\text { To ensure that by } 2010 \text { all protected areas have } \\
\text { effective planning and management plans. }\end{array}$ & ENDS \\
\hline Surveillance of Protected Areas & No target set & NA \\
\hline \multicolumn{3}{|l|}{ Environmental Risks } \\
\hline Forest fires & $\begin{array}{l}\text { By } 2012 \text {, reduce the annual average of burned } \\
\text { area to less than } 100,000 \text { ha }\end{array}$ & ENDS \\
\hline \multicolumn{3}{|l|}{ Urban Waste } \\
\hline Waste Production & $\begin{array}{l}\text { To prevent waste production, by reaching the } \\
\text { following reduction target: }-225,000 \text { tons of } \\
\text { urban waste, from } 2005 \text { to } 2015\end{array}$ & ENDS \\
\hline Waste Management & $\begin{array}{l}\text { By } 2016 \text {, achieve: } 23 \% \text { of landfill disposal, } 27 \% \\
\text { of composting, } 21 \% \text { of incineration, } 19 \% \text { of } \\
\text { recycling, and } 1 \% \text { of Mechanic treatment }\end{array}$ & PERSU $\mathrm{II}^{3}$ \\
\hline $\begin{array}{l}\text { Recycling and Valorization of } \\
\text { Urban Waste }\end{array}$ & $\begin{array}{l}\text { To meet the recycling targets of EU directives } \\
\text { for packaging waste: } 60 \% \text { of paper/carton; } 60 \% \\
\text { of glass; } 50 \% \text { of metal; } 22.5 \% \text { of plastic. }\end{array}$ & ENDS \\
\hline \multicolumn{3}{|l|}{ Energy } \\
\hline $\begin{array}{l}\text { Primary Energy Production and } \\
\text { Consumption }\end{array}$ & $\begin{array}{l}\text { By } 2015 \text {, reduce final energy consumption by } 1 \% \\
\text { per year, compared to the average of the period } \\
2001-2005 \text {. }\end{array}$ & ENDS \\
\hline $\begin{array}{l}\text { Electricity Consumption Produced } \\
\text { from Renewable Energy Sources }\end{array}$ & $\begin{array}{l}\text { By } 2010 \text {, achieve } 39 \% \text { of electricity production } \\
\text { from renewable energy sources }\end{array}$ & ENDS \\
\hline $\begin{array}{l}\text { Energy and Carbon Intensity of } \\
\text { the Economy }\end{array}$ & No target set & NA \\
\hline
\end{tabular}

${ }^{1}$ Strategic Plan for Water Supply and Sanitation 2007-2013.

${ }^{2}$ Estratégia Nacional de Desenvolvimento Sustentavel (Portuguese Sustainable Development Strategy) ${ }^{3}$ Strategic Plan for Urban Waste 2007-2016. 


\section{Quantitative Evaluation of the Sustainable Development Indicators from} 1987 to 2017

For each selected indicator, the trends (increasing or decreasing) and the average growth rate between 1987 and 2017 were identified. The indicators were evaluated from 1987 to 2017 whenever possible.

Once the Portuguese Reports on the State of the Environment are the relevant official documents, and the quality and accuracy of the data are guaranteed, the data used to evaluate the Indicators was collected from these Reports. In order to complete information lacking in those Reports, other reliable official sources were used, such as data from the National Statistical Institute, Water and Waste Services Regulation Authority, and Eurostat (European Statistical Office).

\section{Qualitative Evaluation of the Sustainable Development Indicators}

A simple and concise way to evaluate the progress of sustainability indicators based on a qualitative scale is the "Traffic Light System", which evaluates indicator trends according to 3 colours (green, yellow, red) and is easily understood [17].

This paper applies the Traffic Light System approach to measure trend-based progress of the indicators and also the progress of the indicators towards specific environmental sustainability targets (Target-based indicators).

For all indicators, a trend-based evaluation was carried out, according to the trends found in the quantitative evaluation. To evaluate the selected indicators' progress towards the Portuguese Sustainable Development Strategy, also known as ENDS 2015-Estratégia Nacional de Desenvolvimento Sustentável (ENDS) targets, related goals were identified. For the indicators that did not match any specific ENDS targets, we adopted targets from the specific Sectorial Strategic Plans, such as water and sanitation or waste management strategic plans, covering a significant part of the studied period. For those indicators without specific targets, either in the ENDS or in any Strategic Plans, only a trend-based assessment was carried out. Table 2 shows the targets used. The meaning of the traffic lights is as follows:

Green = Positive trend with significant progress; or meets the defined target;

Yellow $=$ Trend with little or no progress; or some positive development but still insufficient to achieve the target;

Red $=$ Deteriorating trend, or does not meet the target and is far from achieving it;

Grey $=$ No target set, not applicable.

\section{Selection of Indicators for the 2030 Agenda}

To identify which of the selected indicators could also evaluate the goals of the 2030 Agenda for Sustainable Development, a comparative analysis between the selected indicators and the 2030 Agenda SDG indicators were carried out.

\section{Results}

This section of the paper describes the evolution of Portuguese environmental sustainability according to each of the selected indicators, from 1987 to 2017, whenever data are available. The indicators positions relative to the achievement of the targets of the National Sustainable Development Strategy and Sectorial 
Strategic Plans, are evaluated by Traffic Light System approach.

These indicators are also compared with the 2030 Agenda goals, in order to identify which of these indicators could evaluate these SDGs.

Water

The evolution of the water sector indicators showed remarkably good results in most indicators. Portugal's population served with water supply systems showed a growing trend between 1989 and 2009. Its average growth rate was $1.1 \%$ per year. In 1989 , only $63 \%$ of the population was served by public water systems. In 2016, the percentage of houses served with public water supply systems reached $96 \%$ (see Figure 1).

The population served by wastewater drainage and treatment systems increased since 1987, and showed an average growth rate of $1.5 \%$ and $3.1 \%$ per year, respectively. In 1987 less than half of Portugal's population was served by wastewater drainage systems (42\%), and only $4.7 \%$ of the population was served by wastewater treatment systems. In 2016, the percentage of houses served by public wastewater drainage and treatment systems increased to $83 \%$ and $82 \%$, respectively (see Figure 2).

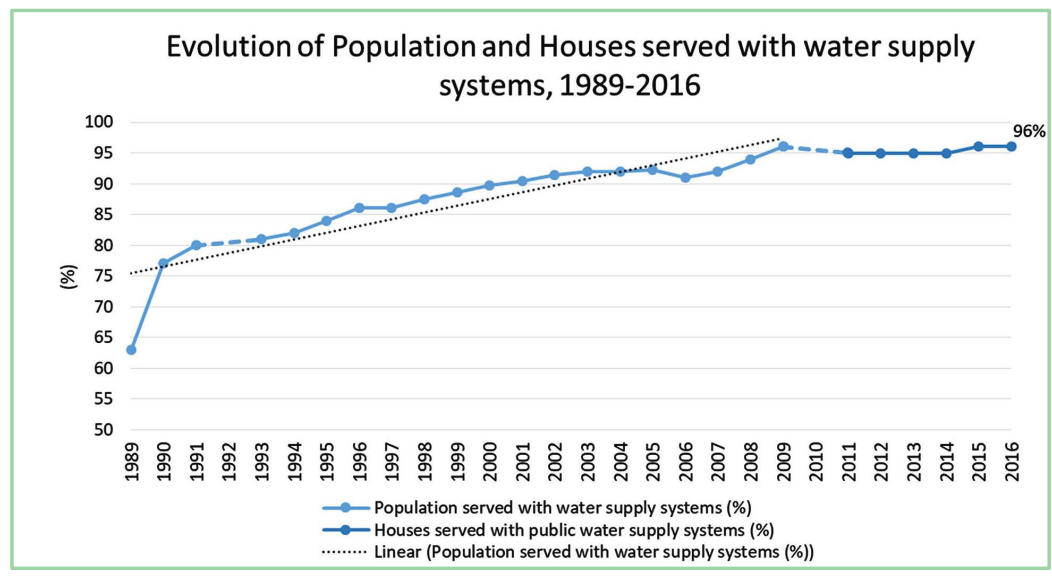

Figure 1. Evolution of Population and Houses served with water supply systems, in mainland Portugal (1989-2016).

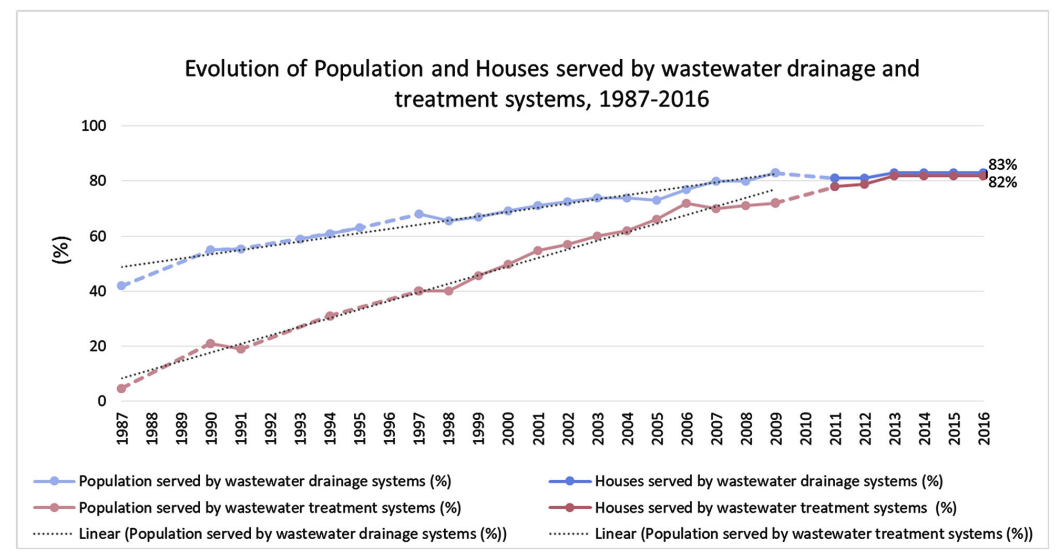

Figure 2. Evolution of Population and Houses served by wastewater drainage and treatment systems, in mainland Portugal (1987-2016). 
The Drinking Water Quality indicator also showed good progress. Despite the growing trend of the percentage of non-compliance water samples with parametric values (PV) in the period 1993-1998, there followed a downward trend, reaching $1.23 \%$ in 2016. Note that the Portuguese legislation between 1998 and 1999 suffered great changes in its quality criteria. The percentage of missing analyses showed a downward trend from 1993 to 2016, reaching 0.08\% in 2016 (see Figure 3).

In terms of Bathing Water Quality, both inland, and coastal or transitional bathing waters showed a growing trend of the class "Excellent" and a downward trend of the class "Bad" quality (see Figure 4 and Figure 5). When analyzing coastal and transitional bathing waters, the class "Excellent" evolved from 51.8\% in 1993 to $89 \%$ in 2016. The class "Bad" evolved from $27.2 \%$ in 1993 to $0.9 \%$ in 2016. In terms of inland bathing waters, the class "Excellent" increased from $4.2 \%$ in 1993 to $69.6 \%$ in 2016. In 1993 the class "Bad" was 12.5\%, reaching $0 \%$ in 2016.

Despite the positive evolution of the water indicators presented, the water consumption indicator showed a growing trend. As Figure 6 displays, Portugal has increased its volume of water consumed, since 1987, as well as volume of water abstracted for public supply, since 1991. Their average growth rates were $0.78 \%$ and $1.13 \%$ per year, respectively.

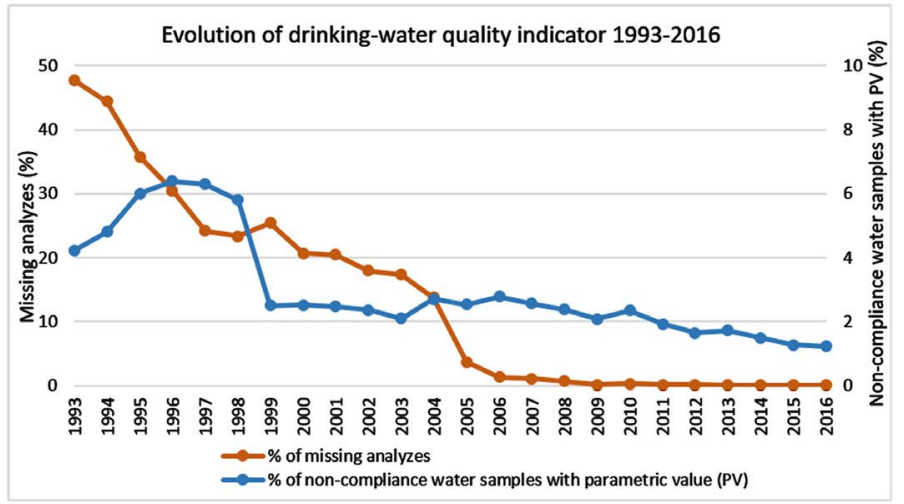

Figure 3. Evolution of drinking-water quality indicator, in mainland Portugal (1993-2016). Note: PV-Parametric Value.

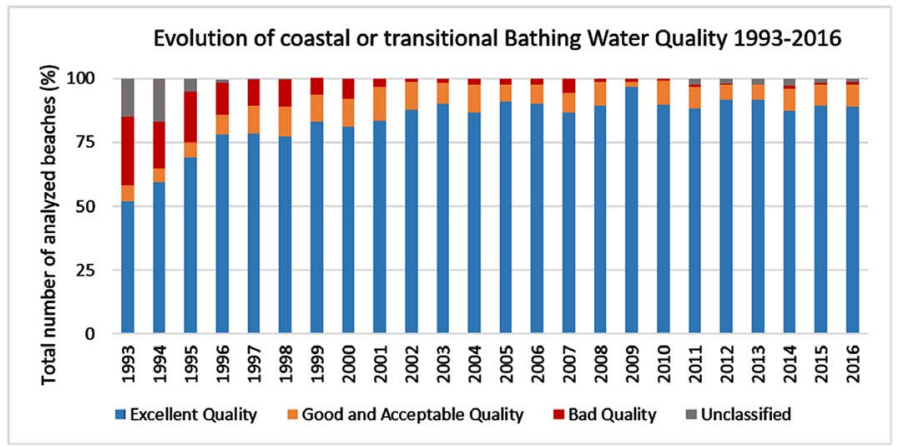

Figure 4. Evolution of coastal or transitional Bathing Water Quality, in Portugal (1993-2016). 


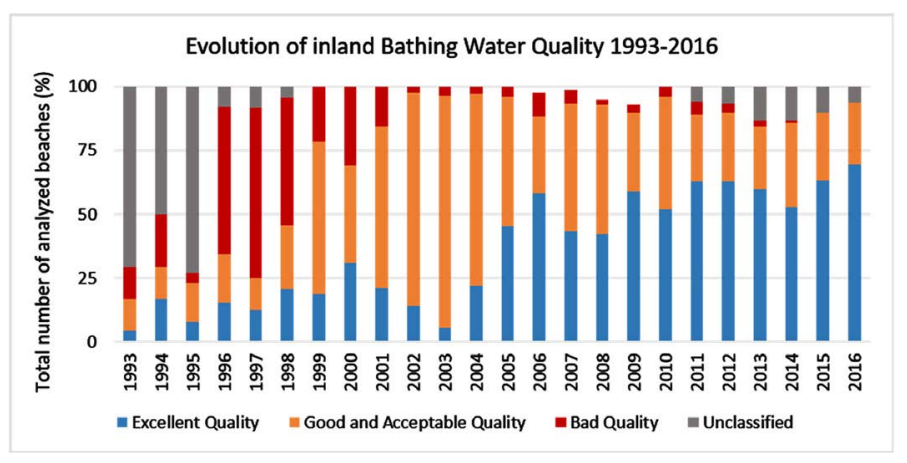

Figure 5. Evolution of inland Bathing Water Quality, in Portugal (1993-2016).

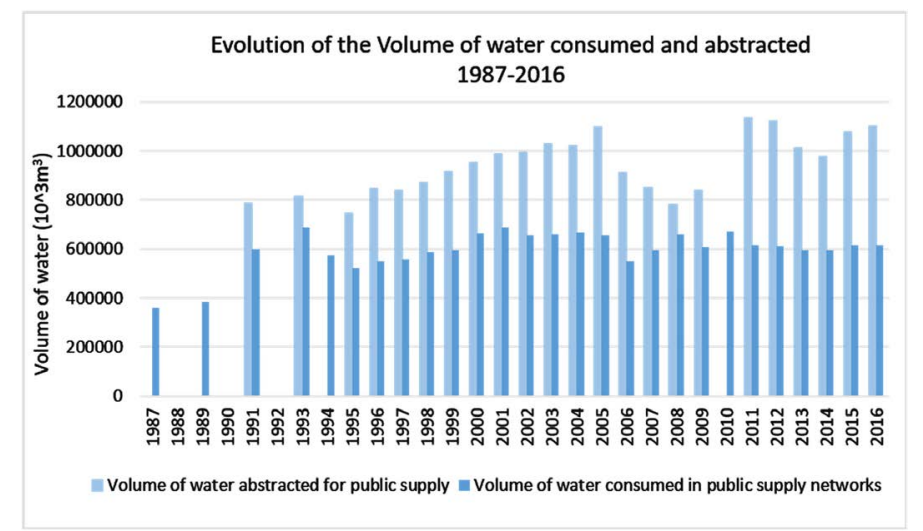

Figure 6. Volume of water consumed in public supply networks (1987-2016) and Volume of water abstracted for public supply (1991-2016), in mainland Portugal.

\section{Air Quality}

Figure 7 sets out Portugal's greenhouse gas (GHG) emissions over the period 1990-2016. During the 1990s, the GHG emissions have continuously increased, reaching a peak in 2005. Since 2005, the GHG emissions showed a downward trend until 2014, and an increase from 2014 to 2015. Between 1990 and 2005, the total emissions without Land Use, Land-Use Change and Forestry (LULUCF) showed an average growth rate of $2.6 \%$ per year. After that period, there was a downward trend with an average growth rate of $-2.5 \%$ per year. Portugal's GHG emissions, without LULUCF, have increased from $59.58 \quad \mathrm{MtCO}_{2} \mathrm{e}$ to 86.31 $\mathrm{MtCO}_{2} \mathrm{e}$ over the period 1990-2005, an increase of $44.9 \%$. By 2016, total GHG emissions without LULUCF were $67.61 \mathrm{MtCO}_{2} \mathrm{e}$, an increase of $13.5 \%$ over 1990. Regarding Portugal's GHG emissions including LULUCF, except for the years 1990, 1991, 2003 and 2005 (extreme forest fires events occurred in these years), this sector was a $\mathrm{CO}_{2}$ sink, representing a sequestration of around $5.39 \mathrm{MtCO}_{2} \mathrm{e}$ in 2016 .

In terms of Air Temperature, the average annual maximum temperature of Portugal, showed a growing trend in the period 1987-2017. Its average growth was $0.025^{\circ} \mathrm{C}$ per year, which corresponds to an increase of $0.75^{\circ} \mathrm{C}$ in the last 30 years. The average annual minimum temperature showed a downward trend in 
the period $1987-2017$. Its average growth was $-0.024^{\circ} \mathrm{C}$ per year, which corresponds to a decrease of $0.72^{\circ} \mathrm{C}$ in the last 30 years. The average annual mean temperature showed no considerable fluctuations in the last 30 years, with an average growth close to zero (see Figure 8).

During the period of data availability, 2002-2016, Portugal's Air Quality showed a positive progress. As Figure 9 shows, the percentage of the number of days with "Very Good" and "Good" air quality index (AQI) registered a growing trend, while the percentage of the number of days classified with "Medium" and "Bad/Weak" registered a downward trend. From 2002 to 2016, the class "Very Good" showed an average growth rate of $0.4 \%$ per year. In 2002 this percentage was $6.4 \%$, increasing to $8.1 \%$ in 2016 . The class "Good" showed an average growth rate of $2.9 \%$ per year, increasing from $30.1 \%$ in 2002 , to $83.2 \%$ in 2016 . The class "Medium" showed an average growth rate of $-2.3 \%$ per year, decreasing from $54.4 \%$ to $7.2 \%$ in the period $2002-2016$. The class "Bad/Weak" showed an average growth rate of $-1 \%$ per year. In 2002 , this percentage was $9.1 \%$, decreasing to $1.5 \%$ in 2016 .

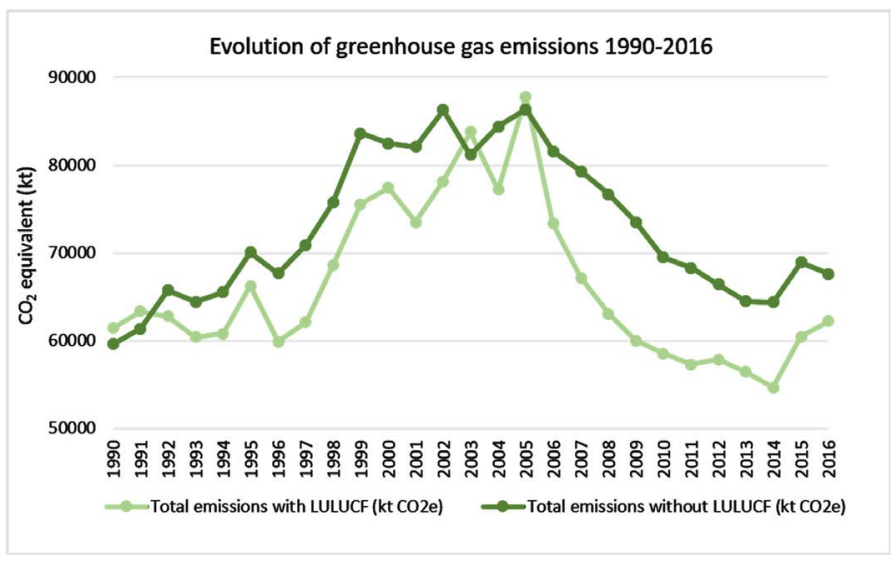

Figure 7. Evolution of greenhouse gas emissions, in Portugal (1990-2016). Note: LULUCF-Land Use, Land-Use Change and Forestry.

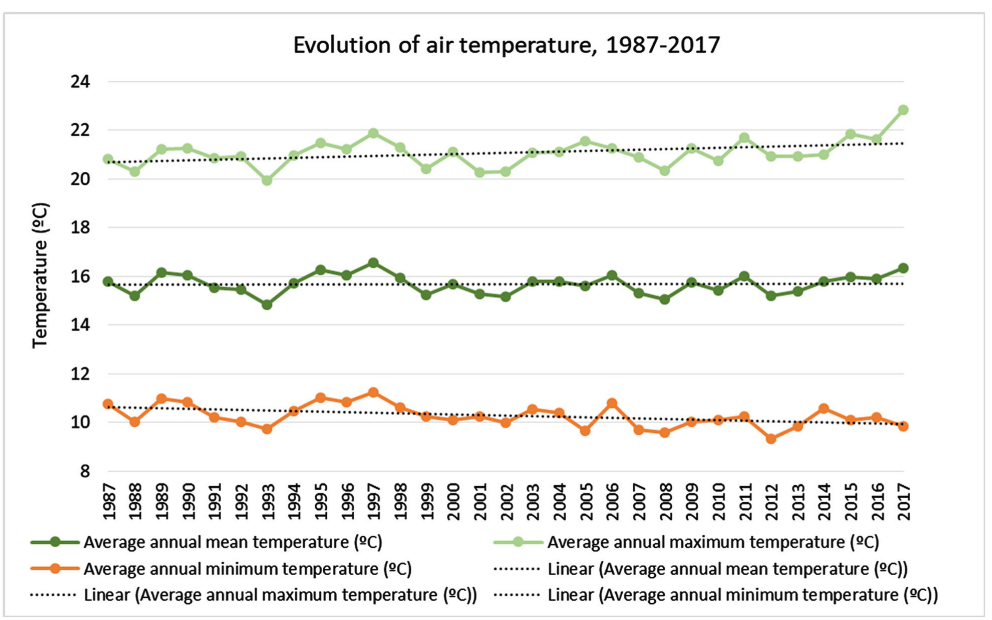

Figure 8. Evolution of air temperature, in mainland Portugal (1987-2017). 


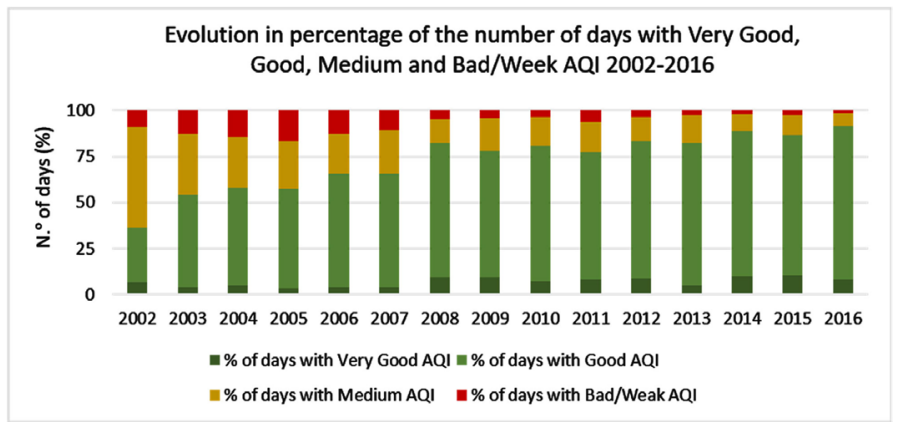

Figure 9. Evolution in percentage of the number of days with Very Good, Good, Medium and Bad/Week AQI (Air Quality Index), in Portugal (2002-2016).

\section{Land Use}

Figure 10 identifies Portugal's percentage of land area of the classes "Land Use and Land Cover" relative to 1986, for the years where data were available (1986-2012). The areas of Forest, Artificial Surfaces, and Water Bodies showed an increasing trend, while the Agricultural Areas, Agriculture with Natural Areas, and Natural Vegetation registered a decreasing trend. In the period 1986-2012, the Forest area and Artificial surfaces registered the greatest growth. The Forest area grew by $1.3 \%$, and the Artificial surfaces grew by $1.2 \%$, corresponding to an average growth rate of $0.055 \%$ and $0.048 \%$ per year, respectively. The area of Natural Vegetation registered the greatest decline (about $-1.1 \%$ ), with an average growth rate of $-0.046 \%$ per year.

\section{Nature and Biodiversity Conservation}

Although Portugal's National Protected Areas Network (NPAN) increased from 1987 to 2017, this growth was feeble. Its average growth rate was only $0.1 \%$ per year. In 2017, the total size of protected land areas in Portugal was 793086.1 ha, which equates to $8.3 \%$ of the continental territory (see Figure 11). In terms of protected area with spatial plans over the period 1987-2017, Portugal's performance shows two periods of growth and two periods of stability. The two periods of growth occurred in 1987-1995, and 2003-2008, with an average growth rate of $5.6 \%$ and $8.4 \%$ per year, respectively. The stability periods occurred in the years 1995-2003, and 2008-2017 (see Figure 12). In 2017, the NPAN area covered by spatial plans was $91.4 \%$ of the total NPAN area. The highest coverage occurred in 2008 (96.8\%).

To supervise protected areas, in 1988 mainland Portugal had only 19 nature rangers, which corresponds to 25,000 ha of protected area per ranger. The highest number of rangers occurred in 1999, with 187 nature rangers. After this year the number started to decrease significantly.

From 1988 to 1990, the surface of protected land areas per nature ranger decreased to 3600 ha per ranger. From that year onwards, there was an increasing trend of this area per ranger. During the period 1990-2017 the average growth rate of surface of protected land areas per nature ranger was $2.4 \%$ per year. In this period, the highest value occurred in 2017, with 6300 ha per nature ranger 
(see Figure 13).

\section{Environmental Risks}

Between 1987 and 2017, the total of burnt forest areas in Portugal showed a growing trend, with an average growth rate of $1.9 \%$ per year. The higher values of burnt areas in Portugal occurred in 2003, 2005 and 2017. In 2017, occurred the highest value of burnt area in the last 30 years, with 456,209 hectares of burnt area. In 2005 there was the highest number of occurrences (35,823 events) (see Figure 14).

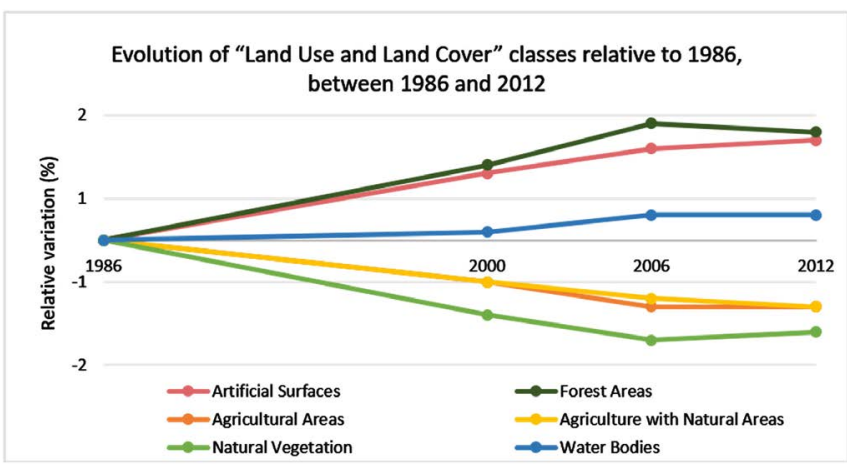

Figure 10. Evolution of "Land Use and Land Cover" classes relative to 1986, in mainland Portugal, between 1986 and 2012.

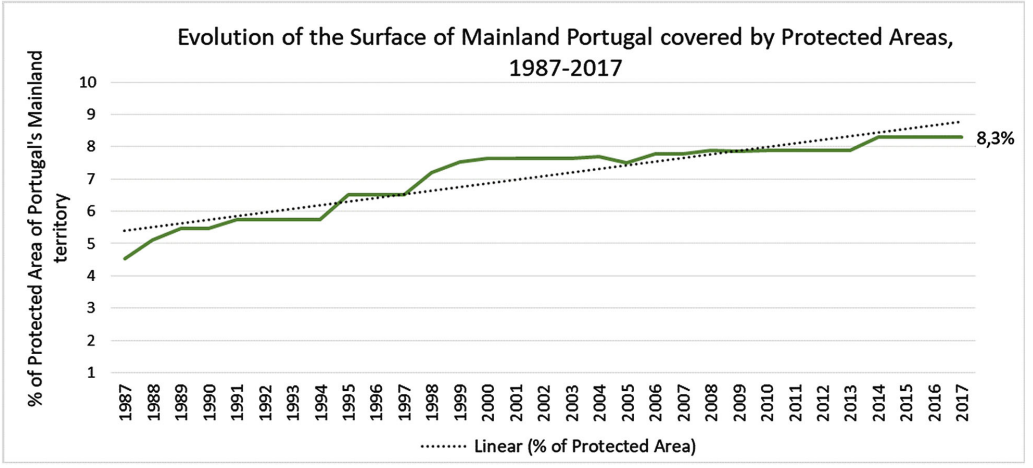

Figure 11. Evolution of the Surface of Mainland Portugal covered by Protected Areas (1987-2017).

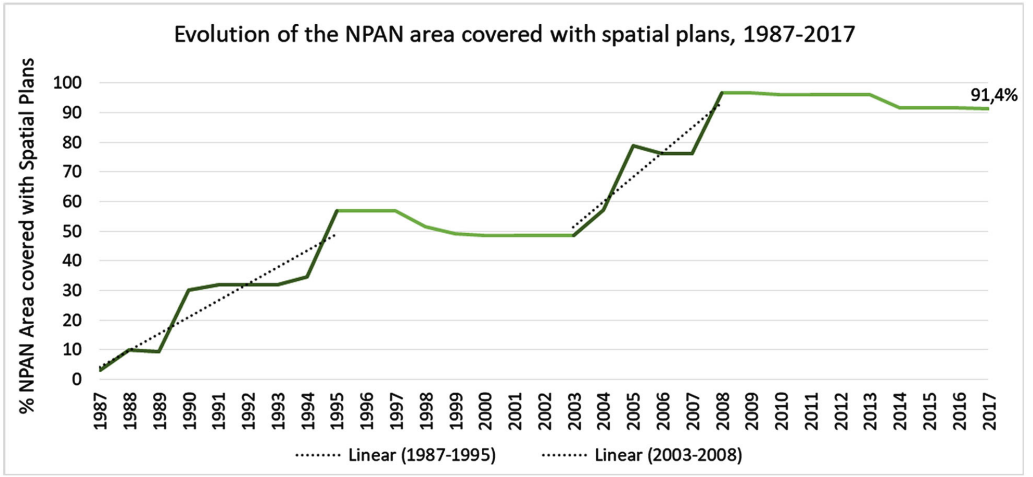

Figure 12. Evolution of the National Protected Areas Network (NPAN) area covered by spatial plans, in Mainland Portugal (1987-2017). 


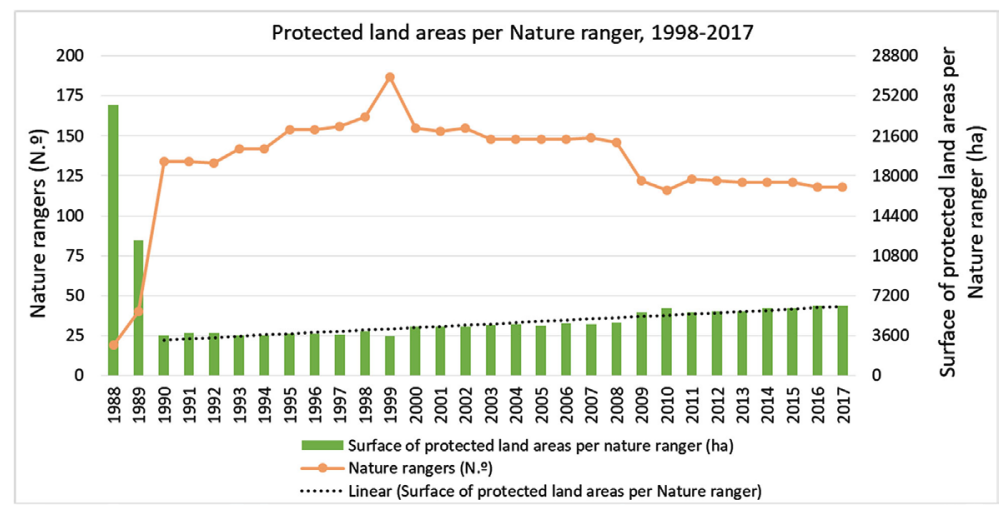

Figure 13. Evolution of the number of nature rangers and of the surface of protected land areas per nature ranger, in Mainland Portugal (1988-2017).

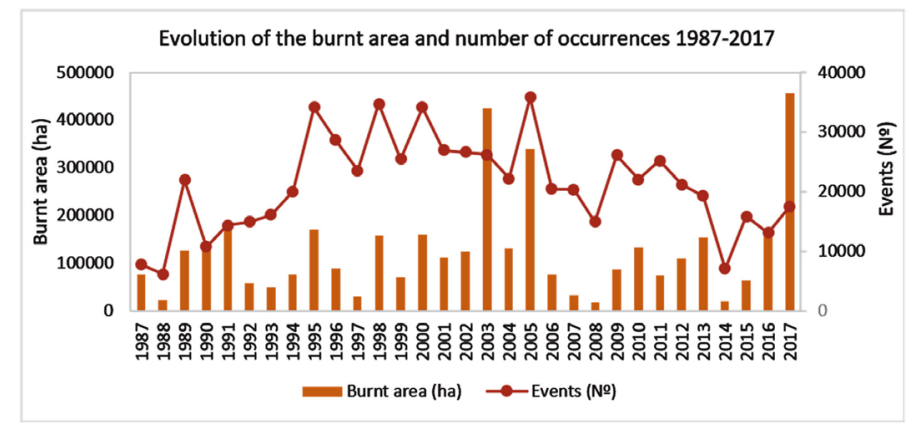

Figure 14. Evolution of the burnt forest area and number of occurrences, in mainland Portugal (1987-2017).

\section{Urban Waste}

Viewed over the period of data availability, 1987-2016 (except for the years 1988, 1991 and 1992, for which information is lacking), Portugal's total and per capita urban waste production showed a growing trend. The average growth rates were $1.74 \%$ and $1.76 \%$ per year, respectively. As Figure 15 shows, in 2009, Portugal registered the highest value of urban waste production (5.19 million tonnes) and also the highest daily per capita value (1.4 kg/inhab/day). From 2009 to 2013, these values decreased. But from 2013 onwards, the Portuguese total and per capita urban waste production showed an increase, reaching 4.64 million tons and $1.29 \mathrm{~kg} / \mathrm{inhab} /$ day respectively, in 2016 . The increase of waste production is strongly related to economic growth and therefore to the increase of society's consumption trends.

As Figure 16 shows, in almost 30 years (1988-2017) Portugal changed its type of waste destination. In 1989, dumps were the main destination of the urban waste (62\% of the total urban waste produced). Between 1989 and 2002, the percentage of waste with this destination showed a downward trend, with an average growth rate of $-4.5 \%$ per year. In 2002 all dumps were eradicated. The destination "Landfill" showed a growing trend in the period 1988-2002, followed by a downward trend between 2002 and 2017. In 1988, the share of urban waste sent to landfill sites was $28 \%$. In 2002 it reached the highest value (74\%), and in 2017 it decreased to $32 \%$. The destinations "organic recovery", "material recov- 
ery", and "incineration/energy recovery", showed a growing trend. It should be noted that the last 2 destinations only appeared in 1998 and 1999 respectively. Municipal solid waste incinerators entered fully in service in the two major metropolitan areas (Valorsul in Lisbon and Lipor at Porto) in 2000. Both treat more than 1000 tonnes of waste per day and produce electricity, corresponding to a power supply capacity of 150,000 inhabitants per year. The Mechanical treatment destination, which consists in removing or processing recyclable waste from a mixed waste stream, only appeared in 2013. In 2017, the main destination of Portuguese waste was the "Landfill" (32\%), followed by "Organic recovery" (30\%), "Incineration/ energy recovery" (21\%), "Material recovery" (11\%), "Mechanical treatment" (6\%) and "Dumps" (0\%).

As Figure 17 shows, the packaging recycling of paper/cardboard, plastic, and metal only started in 1998/99. In general, all recycling rates showed a growing trend. The annual average growth rates were $1.3 \%$ for glass, $1.4 \%$ for paper/cardboard, 2.3\% for plastic, and 3.3\% for metal. Between 1988 and 2016, the recycling rate of glass packaging increased from $16.4 \%$, to $59 \%$. In the period 1998-2016, the recycling rate of paper/cardboard increased from $48 \%$ to $70 \%$. The highest value occurred in 2008 (88\%). As for the plastic packaging, in 1998 its recycling rate was $4 \%$, increasing to $42 \%$ in 2016 . In the period $1999-2015$, the recycling rate of metal increased from $1 \%$ to $64 \%$.

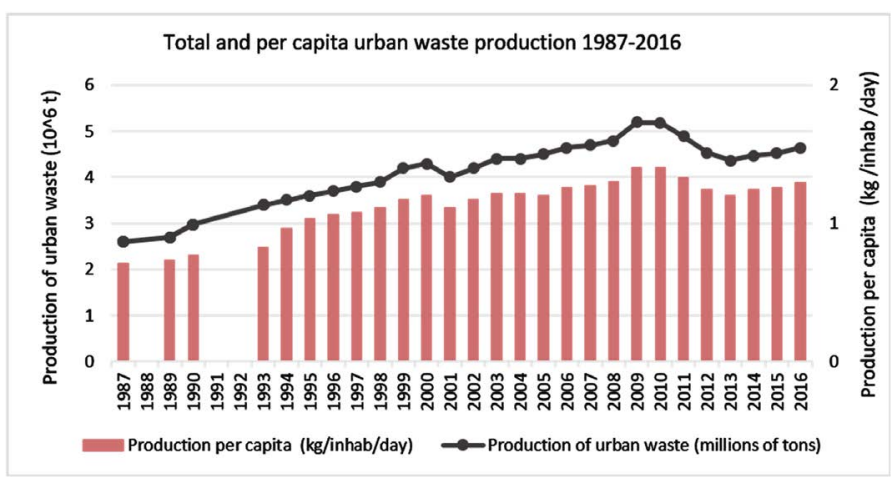

Figure 15. Evolution of total and per capita urban waste production, in mainland Portugal (1987-2016).

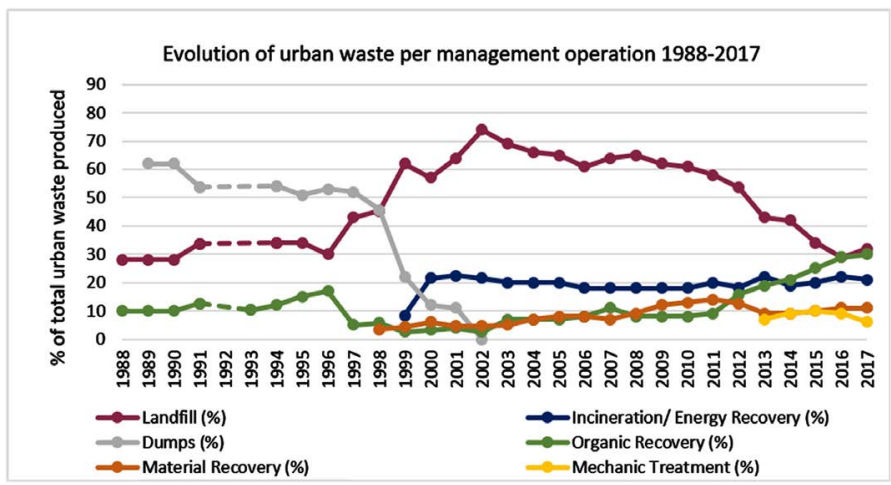

Figure 16. Evolution of urban waste per management operation, in mainland Portugal (1988-2017). 


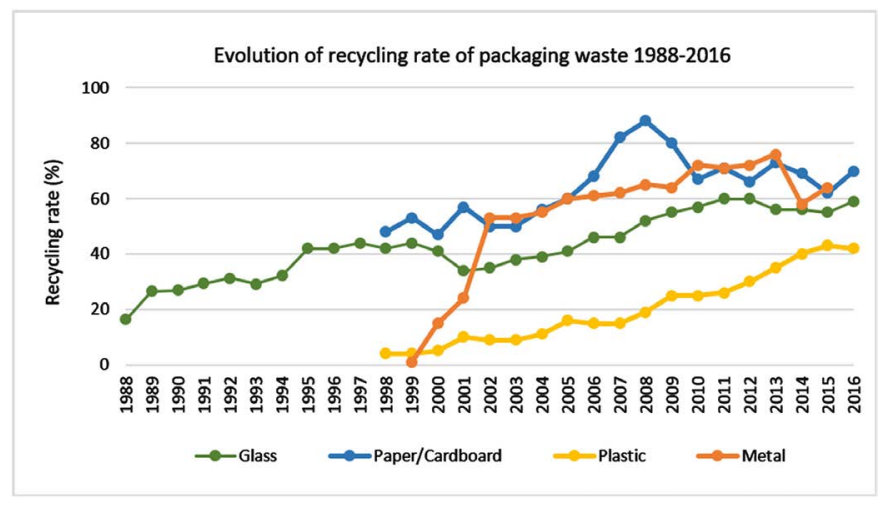

Figure 17. Evolution of recycling rate of packaging waste, in Portugal (1988-2016).

\section{Energy}

Portugal's primary energy production showed a growing trend between 1990 and 2016, with an average growth rate of $2.4 \%$ per year. During this period it increased from 3.4 million tonnes of oil equivalent (Mtoe) to 5.9 Mtoe. Primary energy consumption, despite the growing trend in the period 1990-2005, showed a downward trend afterwards. Actually, from 1990 to 2005 its annual average growth rate was $4 \%$, and during the period 2005-2016 it was $-2.2 \%$. In 1990, the primary energy consumption was 16.1 Mtoe, reaching the highest value in 2005 (27.5 Mtoe). Afterwards it decreased, reaching 21.8 Mtoe in 2016 (see Figure 18).

Regarding the energy produced from Renewable Energy Sources (RES), the hydric component (hydroelectric power) was the main contributor to the production of renewable energy in Portugal, in an early stage. However, since 2006 the other RES began to contribute more to this production. In 2017, Portugal's energy produced from RES was mainly due to the mix "Wind" (12,000 GWh) and "Hydro" (7500 GWh), followed by the components "Biomass + Solid Urban Waste (SUW) + Biogas" (3200 GWh), "Photovoltaic" (1000 GWh) and "Geothermal" (200 GWh). The share of RES in total electricity produced showed a growing trend, with an average growth rate of $1 \%$ per year. In 1994, this share was 36\%, reaching its maximum in 2016 (62\%). In 2017 this share was $44 \%$. Despite its growing trend, the share of RES in total electricity produced fluctuated greatly, mainly because of the variation of hydroelectric production. In the years 1995, 1999, 2002, 2004, 2005, 2012, 2015 and 2017, growth falls were registered, owing to the occurrence of droughts in those years (drop in hydroelectric production) (see Figure 19).

Figure 20 shows the energy and carbon intensity of the Portuguese economy during the period 1995-2016. Between 1995 and 2005, the economy's energy and carbon intensity showed a downward trend, but with considerable fluctuations. Since 2005, a continuous downward trend can be observed, indicating the beginning of a continuous process of "decarbonization" of the Portuguese economy. From 2005, the Portuguese economy has been emitting less carbon per unit of wealth produced, and consuming less energy. In 1995 Portugal recorded an 
energy intensity of 171.1 toe/M€'1995, decreasing to 133 toe/M€'2010 in 2016. In terms of carbon intensity, in the period 1995-2015, Portugal decreased from 0.64 $\mathrm{kg} \mathrm{CO} 2 \mathrm{e} / € G D P$, to $0.40 \mathrm{~kg} \mathrm{CO}_{2} \mathrm{e} / € G D P$.

\section{Qualitative Evaluation of the Sustainable Development Indicators}

Table 3 summarizes the performance of Portugal with respect to trend and target-based evaluation. In terms of trend-based evaluation, eleven out of eighteen indicators showed positive trend with significant progress (green), one indicator showed little progress (yellow), and six indicators showed a negative trend (red).

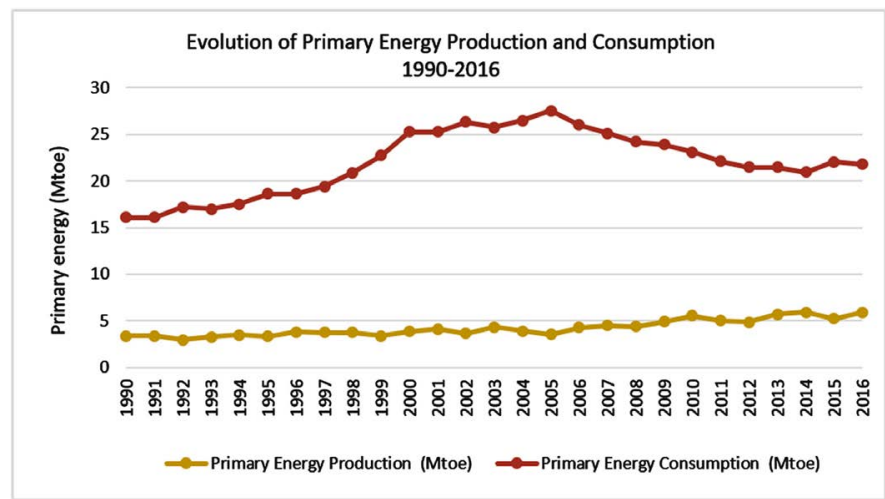

Figure 18. Evolution of Primary Energy Production and Consumption, in Portugal (1990-2016).

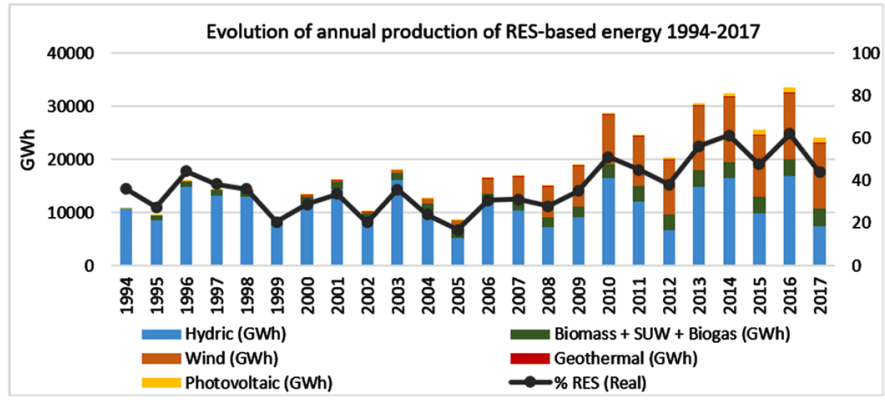

Figure 19. Evolution of annual production of RES-based energy, in Portugal (1994-2017). Note: RES-Renewable Energy Sources, and SUW-Solid Urban Waste.

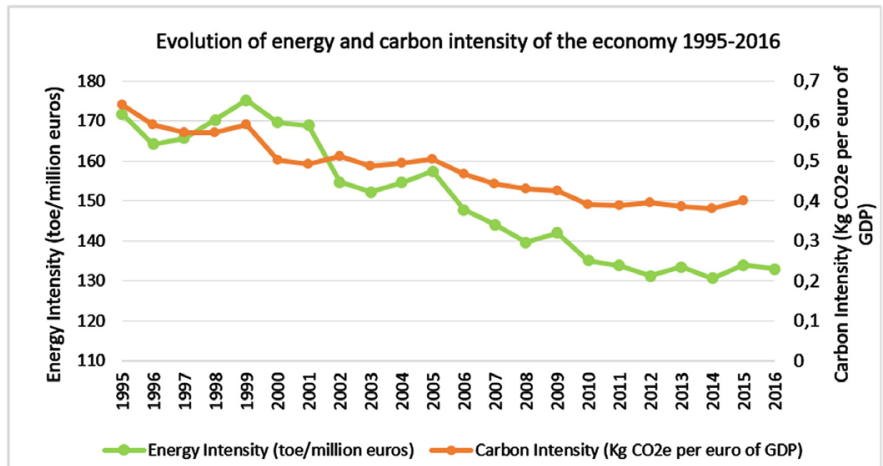

Figure 20. Evolution of energy and carbon intensity of the economy, in Portugal (1995-2016). Note: GDP_Gross domestic product. 
Table 3. Trend-based and Target-based environmental sustainability performance of Portugal: Traffic Light table.

\begin{tabular}{|c|c|c|c|c|}
\hline Theme & Indicator & Trend & $\begin{array}{l}\text { Target } \\
\text { achievement }\end{array}$ & Justification and explanation \\
\hline \multirow{7}{*}{ Water } & $\begin{array}{l}\text { Population served with Water } \\
\text { Supply Systems }\end{array}$ & & & $\begin{array}{l}\text { The target of } 95 \% \text { was met, serving } 96 \% \text { of the population in } \\
2009 \text {, and } 96 \% \text { of houses in } 2016 \text {. }\end{array}$ \\
\hline & Population served by & & & Despite the great progress, the target of $90 \%$ wasn't met. In \\
\hline & Wastewater Drainage and & & & 2009 , only $83 \%$ and $72 \%$ of the population was served by \\
\hline & Treatment Systems & & & Wastewater Drainage and Treatment Systems, respectively. \\
\hline & Water Consumption & & & $\begin{array}{l}\text { The volume of water consumed and abstracted showed an } \\
\text { increasing trend. }\end{array}$ \\
\hline & Drinking-water Quality & & & $\begin{array}{l}\text { Despite the positive evolution the target was not met. } \\
\text { However, it's very close to be achieved. }\end{array}$ \\
\hline & Bathing Water Quality & & & $\begin{array}{l}\text { The progress was very positive. In } 2016 \text {, less than } 1 \% \text { of } \\
\text { coastal and transitional bathing waters, and } 0 \% \text { of inland } \\
\text { waters were classified with "Bad" quality. }\end{array}$ \\
\hline & Greenhouse Gas Emissions & & & $\begin{array}{l}\text { The target of limiting GHG emissions growth to } 27 \% \\
\text { compared to } 1990 \text { was met, increasing only } 19 \% \text {. }\end{array}$ \\
\hline Air Quality & Air Temperature & & & $\begin{array}{l}\text { This indicator showed a deteriorating trend, with an increase } \\
\text { and decrease of almost } 1^{\circ} \mathrm{C} \text { of the average of the maximum } \\
\text { and minimum temperature, respectively. }\end{array}$ \\
\hline & Air Quality & & & $\begin{array}{l}\text { The air quality showed a positive evolution. In } 2016 \text {, more } \\
\text { than } 90 \% \text { of the days registered "Very Good" and "Good" } \\
\text { AQI, and less than } 1 \% \text { registered "Bad/Weak". }\end{array}$ \\
\hline Land Use & Land Use and Land Cover & & & $\begin{array}{l}\text { This indicator showed a deteriorating trend. Since } 1986 \text { the } \\
\text { artificial surfaces have increased, while natural vegetation, } \\
\text { and agriculture areas have been replaced. }\end{array}$ \\
\hline \multirow{3}{*}{$\begin{array}{l}\text { Nature and } \\
\text { Biodiversity } \\
\text { Conservation }\end{array}$} & Classified Areas for Nature and & & & $\begin{array}{l}\text { The target was not met. The growth of classified areas was } \\
\text { feeble, and despite the positive evolution of protected areas }\end{array}$ \\
\hline & Biodiversity Conservation & & & $\begin{array}{l}\text { with spatial plan, only one protected area is covered by } \\
\text { management plan. }\end{array}$ \\
\hline & Surveillance of Protected Areas & & & $\begin{array}{l}\text { Since } 1990 \text {, the surface of protected areas per nature ranger } \\
\text { increased. In 2017, there were only } 118 \text { nature rangers for } \\
\text { mainland Portugal. }\end{array}$ \\
\hline $\begin{array}{l}\text { Environmental } \\
\text { Risks }\end{array}$ & Forest fires & & & $\begin{array}{l}\text { The target of } 100,000 \text { ha of burnt area by } 2012 \text { was not met, } \\
\text { and in } 2017 \text { more than } 450,000 \text { ha were burnt. }\end{array}$ \\
\hline \multirow{3}{*}{ Urban Waste } & Waste Production & & & $\begin{array}{l}\text { The target of reducing } 225,000 \text { tons of urban waste, from } \\
2005 \text { to } 2015 \text { was not met. In this period it increased } 20,000 \\
\text { tons. }\end{array}$ \\
\hline & Waste Management & & & $\begin{array}{l}\text { Although the targets of composting, incineration, and } \\
\text { mechanic treatment have been met, the targets of landfill } \\
\text { disposal and recycling are still not being achieved. The } \\
\text { landfill disposal needs to decrease } 6 \% \text {, and the recycling } \\
\text { needs to increase } 8 \% \text {. }\end{array}$ \\
\hline & $\begin{array}{l}\text { Recycling and Valorization of } \\
\text { Urban Waste }\end{array}$ & & & $\begin{array}{l}\text { The recycling targets were met for all types of packaging } \\
\text { waste. }\end{array}$ \\
\hline \multirow{3}{*}{ Energy } & $\begin{array}{l}\text { Primary Energy Production and } \\
\text { Consumption }\end{array}$ & & & $\begin{array}{l}\text { The target of reducing } 2.6 \text { Mtoe of the final energy } \\
\text { consumption by } 2015 \text { was met, with a reduction of } 5.5 \text { Mtoe. }\end{array}$ \\
\hline & $\begin{array}{l}\text { Electricity Consumption } \\
\text { Produced from Renewable } \\
\text { Energy Sources }\end{array}$ & & & $\begin{array}{l}\text { The target of achieving } 39 \% \text { of electricity produced from RES } \\
\text { by } 2010 \text { was met, producing more than } 50 \% \text { for that year. }\end{array}$ \\
\hline & $\begin{array}{l}\text { Energy and Carbon Intensity of } \\
\text { the Economy }\end{array}$ & & & $\begin{array}{l}\text { The progress of this indicator was very positive. It showed an } \\
\text { evolution to an economy with lower energy consumption, } \\
\text { and with less carbon emitted per unit of wealth produced. }\end{array}$ \\
\hline
\end{tabular}


In terms of target-based evaluation, Portugal met five out of eleven targets, with successes relating to population served with water supply systems, GHG emissions, recycling and valorization of urban waste, primary energy production and consumption, and electricity consumption produced from RES. Four indicators showed positive development; still insufficient but close to achieving the targets. The forest fires, and waste production indicators did not meet the targets and are far from achieving them. Table 3 summarizes the justifications and explanations.

For three indicators (population served by wastewater drainage and treatment systems, drinking-water quality, and waste management indicators), despite the positive progress over the years, the targets were not achieved. Note also that there are seven indicators for which Portugal did not apply any targets (grey).

\section{Selection of Indicators for the 2030 Agenda}

Table 4 shows that 11 of the 18 selected indicators are related to the 2030 Agenda goals. The match between SIDS and SDG indicators reveals that 8 of the SDG targets can be evaluated. These targets are related to Goals 6 ("Ensure availability and sustainable management of water and sanitation for all"), 7 ("Ensure access to affordable, reliable, sustainable and modern energy for all"), 11 ("Make cities and human settlements inclusive, safe, resilient and sustainable"), 12 ("Ensure sustainable consumption and production patterns"), and 15 ("Protect, restore and promote sustainable use of terrestrial ecosystems, sustainably manage forests, combat desertification, and halt and reverse land degradation and halt biodiversity loss") [22]. Table 4 identifies SDG indicators and their match with SIDS indicators, and their corresponding SDG targets. It also shows the year from which these indicators can be evaluated in Portugal (data availability).

\section{Discussion}

During the last decades, the EU has developed a large range of environmental legislation, to reduce significantly water, air, and soil pollution. According to the European Commission, "the EU has nowadays one of best water qualities in the world, and over $18 \%$ of the EU's territory has been designated as protected areas" [24].

In order to provide a general policy framework for the EU's environment policy, 7 Environmental Action Programmes were developed. The Environmental Action Programmes, defining the most important medium and long-term goals, have guided European environment policy since the early 1970s. The 4th Environmental Action Programme (1987-1992) marks a turning point in European environmental policy. With this programme, environmental policy came to be seen as part of the economic decision-making process, and not as an additive/corrective policy. For the first time, incentive-based instruments were set, such as taxes, subsidies or tradable emission permits [25]. The 5th Environmental Action Programme (1993-2000), was prepared alongside the Rio Conference (1992) and Agenda 21, and represented the first commitment of the 
Community towards sustainable development [26]. The 6th Environmental Action Programme (2002-2012) sets out a framework of general objectives, on key issues, such as climate change, biodiversity threats, excessive consumption of resources, recycling, soil, and fresh air [25]. The 7th Environment Action Programme (2014-2020) will guide European environment policy until 2020. This programme aims to increase the ecological resilience of the EU economy, and transform the European economy to provide a green, sustainable and inclusive growth [24].

Table 4. Comparative analysis between the SIDS and SDG indicators Data source: [15] [22] [23].

\begin{tabular}{llll}
\hline 2030 Agenda SDG Targets & SDG indicators & SIDS indicators & Data availability
\end{tabular}

Goal 6 (Clean Water and Sanitation)

Target 6.1: By 2030, achieve universal and equitable access to safe and affordable drinking water for all

Target 6.2: By 2030, achieve access to adequate and equitable sanitation and hygiene for all and end open defecation, paying special attention to the needs of women and girls and those in vulnerable situations

Target 6.3: By 2030, improve water quality by reducing pollution, eliminating dumping and minimizing release of hazardous chemicals and materials, halving the proportion of untreated wastewater and substantially increasing recycling and safe reuse globally

\section{Goal 7 (Affordable and Clean Energy)}

Target 7.2: By 2030, increase substantially the Renewable energy share in the total share of renewable energy in the global energy mix final energy consumption

Target 7.3: By 2030, double the global rate of improvement in energy efficiency

Energy intensity measured in terms of primary energy and GDP

Proportion of population using safe managed drinking water services

Population served with Water

Supply Systems

Drinking-water Quality

Since 1989

Proportion of population using safely managed sanitation services, including a hand-washing facility with soap and water

Population served by Wastewater Drainage and Treatment Systems

Proportion of wastewater safely treated

Since 1993

Proportion of bodies of water with good ambient water quality

Bathing Water Quality

Since 1987

Electricity Consumption Produced from Renewable Energy Sources

Energy and Carbon Intensity of the Economy

Since 1995

\section{Goal 11 (Sustainable Cities and Communities)}

Target 11.6: By 2030, reduce the adverse per capita environmental impact of cities, including by paying special attention to air quality and municipal and other waste management

Annual mean levels of fine particulate matter (e.g. PM2.5 and PM10) in Air Quality

Since 2002

cities (population weighted)

Proportion of urban solid waste regularly collected and with adequate Waste Management

Since 1988 final discharge out of total urban solid waste generated, by cities

\section{Goal 12 (Responsible Consumption and Production)}

Target 12.5: By 2030, substantially reduce waste generation through prevention, reduction, recycling and reuse

\section{Goal 15 (Life on Land)}

Target 15.1: By 2020, ensure the conservation, restoration and sustainable use of terrestrial and inland freshwater ecosystems and their services, in particular forests, wetlands, mountains and drylands, in line with obligations under international agreements
National recycling rate, tons of material recycled

Recycling and Valorization of Urban Waste

Since 1988

Forest area as a proportion of total land area

Land Use and Land Cover

Since 1986

Proportion of important sites for

terrestrial and freshwater biodiversity Classified Areas for Nature and that are covered by protected areas, by Biodiversity Conservation ecosystem type
Since 1987 
The accession of Portugal to the European Economic Community, in 1986, brought several economic benefits to the country. With the support of the European Regional Policy, Portugal's standards became those of the other EEC members. Over the last 30 years, the support of EU funds and the development of environmental public policies in Portugal, driven by community commitments, have been essential for the development of the country, particularly in terms of environmental issues [27].

The water, air quality, urban waste, and energy sectors showed a positive evolution, achieving good results in most indicators. On the other hand, in sectors like the land use evolution was not so positive, and regarding environmental risks, particularly forest fires, there has been a negative trend.

In 1987, Portugal's water supply systems, and wastewater drainage and treatment systems were poorly developed. Only $4.7 \%$ of the Portuguese population was served by Treatment Systems. The support of Community funds, plus the systematic elaboration of Strategic Plans by the Portuguese government, changed the water sector in Portugal. Currently, the percentage of the population served by water supply, and wastewater drainage and treatment systems (more than 80\%) is within the average of the 28 European Union member states (EU-28). The increase of the population with access to sanitation services, the expansion of the drainage network and domestic wastewater treatment plants (WWTPs), and the reduction of effluent nutrient concentrations owing to better wastewater treatments, had a positive impact on drinking-water quality, and bathing water quality. According to Eurostat, in 2016, Portugal's share of coastal and transition bathing waters classified with "Excellent" (89\%) was higher than the EU-28 average (87\%). In terms of inland bathing waters, Portugal is approaching the EU-28 average. In 2016, Portugal's share of inland bathing waters classified with "Excellent" was 69.6\%, and the EU-28 average was 82\% [11] (see Table 5). The increasing trend of the volume of water consumed and abstracted can be explained by several factors: population growth, the new consumption habits [28], more tourism activity, water losses in transport and distribution systems, and inefficient water use [29]. Since 2000, significant investments have reduced losses in storage, transportation and distribution systems. These efforts resulted from legal obligations, such as the EU Water Framework Directive. In $2000,40 \%$ of the water abstracted was lost [28], decreasing to $20 \%$ in 2016 [30].

The evolution of GHG emissions reflects the evolution of the Portuguese economy. In the 1990s, the Portuguese economy was characterized by energy and mobility demand. From 2005, GHG emissions have been decreasing because of technological improvements, such as pollution control and energy efficiency systems. The introduction of cleaner alternative fuels in 1997, such as natural gas; the increase of energy produced from RES; the decrease of landfill disposal; the increase of recycling and reduced industrial activities in the country, owing to the economic crisis (2010-2014), also contributed to the decrease of GHG emissions. The increase in GHG emissions from 2014 can be explained by the 
Table 5. Comparison of several indicators between Portugal and the European Union, in most recent years of data availability. Sources: [11] [34] [38] [43] [44].

\begin{tabular}{|c|c|c|c|}
\hline Indicators & Year & EU-28 & Portugal \\
\hline Houses served with water supply systems & 2016 & $>80 \%$ & $96 \%$ \\
\hline $\begin{array}{l}\text { Houses served by wastewater drainage and } \\
\text { treatment systems }\end{array}$ & 2016 & $>80 \%$ & $83 \%$ and $82 \%$ \\
\hline $\begin{array}{l}\text { Coastal and transitional bathing waters with } \\
\text { "Excellent" Quality }\end{array}$ & 2016 & $87 \%$ & $89 \%$ \\
\hline $\begin{array}{l}\text { Inland bathing waters with "Excellent" } \\
\text { Quality }\end{array}$ & 2016 & $82 \%$ & $69.6 \%$ \\
\hline GHG emissions & 2016 & 8.7 t per capita & $6.9 \mathrm{t}$ per capita \\
\hline $\begin{array}{l}\text { Urban population exposure to air pollution } \\
\text { (Particulates }<2.5 \mu \mathrm{m} \text { ) }\end{array}$ & 2014 & $15.2 \mu \mathrm{g} / \mathrm{m}^{3}$ & $9.9 \mu \mathrm{g} / \mathrm{m}^{3}$ \\
\hline $\begin{array}{l}\text { Urban population exposure to air pollution } \\
\text { (Particulates }<10 \mu \mathrm{m})\end{array}$ & 2014 & $22.5 \mu \mathrm{g} / \mathrm{m}^{3}$ & $20 \mu \mathrm{g} / \mathrm{m}^{3}$ \\
\hline Area of Artificial Surface & 2012 & $4 \%$ & $5.2 \%$ \\
\hline $\begin{array}{l}\text { Proportion of land area covered by Natura } \\
2000 \text { network }\end{array}$ & 2018 & $18.2 \%$ & $20.7 \%$ \\
\hline Urban waste production & 2014 & $1700 \mathrm{~kg}$ per capita & $1200 \mathrm{~kg}$ per capita \\
\hline Share of urban waste sent to landfill & 2014 & $133 \mathrm{~kg}$ per capita & $222 \mathrm{~kg}$ per capita \\
\hline Share of urban waste sent to organic recovery & 2014 & $75 \mathrm{~kg}$ per capita & $64 \mathrm{~kg}$ per capita \\
\hline Share of urban waste sent to incineration & 2014 & $125 \mathrm{~kg}$ per capita & $94 \mathrm{~kg}$ per capita \\
\hline Share of urban waste sent to material recovery & 2014 & $134 \mathrm{~kg}$ per capita & $74 \mathrm{~kg}$ per capita \\
\hline Share of recycled packaging in total produced & 2015 & $65.7 \%$ & $57.1 \%$ \\
\hline Primary Energy Consumption & 2016 & 55.1 Mtoe & 21.8 Mtoe \\
\hline $\begin{array}{l}\text { Share of "hydric" component in total } \\
\text { electricity production }\end{array}$ & 2016 & $10.8 \%$ & $26.1 \%$ \\
\hline $\begin{array}{l}\text { Share of "wind" component in total electricity } \\
\text { production }\end{array}$ & 2016 & $9.3 \%$ & $20.7 \%$ \\
\hline $\begin{array}{l}\text { Share of "Photovoltaic" component in total } \\
\text { electricity production }\end{array}$ & 2016 & $3.2 \%$ & $1.4 \%$ \\
\hline Energy intensity of the economy & 2016 & 119 toe/M€’2010 & 133 toe/M€’2010 \\
\hline Carbon intensity of the economy & 2015 & $0.3 \mathrm{~kg} \mathrm{CO} 2 \mathrm{e} / € \mathrm{GDP}$ & $0.4 \mathrm{~kg} \mathrm{CO} 2 \mathrm{e} / € \mathrm{GDP}$ \\
\hline
\end{tabular}

drop in hydroelectric production, because of the drought that occurred then [31]. Portugal is one of the European Union countries with the lowest GHG emissions per capita. Since 1990, these emissions were always below the EU-28 average. In 2016, the EU-28 average was 8.7 tonnes per capita, and the Portuguese GHG emissions were 6.9 tonnes per capita [11] (see Table 5). The GHG emissions are one of the main causes of global warming, since the mid-twentieth century. Despite the increasing number of climate change mitigation policies, GHG emissions continue to increase, leading to extreme climatic events [32]. The implementation of EU policies, such as the National Emission Ceilings Directive, and the Directive for ambient air quality and cleaner air for Europe (Di- 
rective 2008/50/EC), contributed to the positive evolution of air quality in Portugal [33] The directive's targets, of achieving an effective protection of both human health and environment against risks from air pollution throughout the EU, apply through the EU's Fifth and Sixth Environmental Action Programmes. Table 5 shows that the number of citizens exposed in urban centres to air pollution is below the EU-28 average [34].

In Portugal the artificial surfaces have increased, replacing natural vegetation and agricultural areas [35]. This increase can be explained by the development of the country, through economic growth [36]. According to Eurostat, in 2012 the percentage of artificial surfaces in Portugal (5.2\%) was higher than the EU-28 average (4\%) [34]. The community funds, and the environmental and agricultural measures to support afforestation, can explain the increase of forest area in Portugal. Industrial demand for cellulose, profits, and the rapid growth of eucalyptus have led to a significant increase of this species, production of which was at first environmentally unsustainable. Portugal's commitment to increase renewable energies has led to a great investment in water use infrastructures (such as dams and water reservoirs) [36].

Portugal's acceptance of practically all the international conventions concerning environmental problems is the main cause of development of the nature and biodiversity conservation sector in the country. In 1993, Portugal approved the ratification of the Convention on Biological Diversity (CBD), coming into force in 1994 [37]. In 1999, Portugal adopted the main instrument for nature conservation in the European Union, the Natura 2000 network. This instrument was adopted through the ratification of the conservation of wild birds (79/409/EEC) and the preservation of natural habitats and wild flora and fauna (92/43/EEC) Directives. Despite the feeble growth of protected areas in Portugal, the Natura 2000 network resulted in a case of success for the nature and biodiversity conservation in the country. Currently, the Natura 2000 network in Portugal covers about $20.7 \%$ of the total land area, plus about $39,000 \mathrm{~km}^{2}$ of the marine area. According to the Natura 2000 Barometer, developed by the European Commission, Portugal is above the EU-28 average (18.2\%) [38]. In terms of Surveillance of Protected Areas, the number of nature rangers did not follow the growth of the NPAN area, compromising the management effectiveness, and the protection of the faunal, floristic, architectural and cultural heritage of these areas [39].

According to the European Commission Forest Fires Report, in 2017 Portugal had the most burnt area of the EU-28 (more than 450,000 ha). In 2017 the share of burnt area in Portugal was 59\% of the total of the five Southern Member States, followed by Spain (19\%), Italy (18\%), France (3\%) and Greece (1\%) [40]. Several factors, such as rural abandonment, absence of land use management, Portugal's climate conditions with rainy seasons followed by dry and hot periods, and the increase of highly flammable species, such as Pinus pinaster and Eucalyptus globulus contributed to the increase of forest fires in the country 
[41]. Furthermore, the significant decrease in the number of rangers during the last decade has led to the situation that, precisely in 2017, each nature ranger had an average of 6300 ha to survey, meaning a reduction of almost $50 \%$ of the human resources - another consequence of financial crisis. It is agreed that the number of criminal fires increased significantly during the considered period, but even official sources disagree on the figures. An Independent Commission nominated by the Government in 2018 to analyse the problematic of forest fires, stated that, although $98 \%$ of ignitions had human origin, they were a mixture of arson, negligence and simple accidents. The government has recently launched a deep reform of forest management, forest fire prevention, vigilance and public awareness campaigns.

The increase of waste urban production over the last 30 years, may be related to the improvement of the Portuguese economic situation. The decrease of urban waste production between 2009 and 2013, corresponds to the period of economic crisis in the country. Economic growth and consumer spending go together, and more waste is generated when the economy goes well [31]. Despite the waste production increase, according to Eurostat, in 2014 the Portuguese waste production (1200 kg per capita) was below the EU-28 average (1700 kg per capita) [11] (see Table 5). In terms of waste management, the implementation of the first Strategic Plan for Urban Waste (PERSU I) in 1997, was the main contributor to eradicate all dumps in Portugal. With the total eradication of dumps in 2002, the landfill destination started to increase. Landfills are engineered deposits of organic urban waste with controlled emissions and a proper engineered systems to treat seeping liquids. In order to comply with the Landfill Directive (Directive 1999/31/EC of 26 April 1999) obligations, in 2003 the Portuguese government implemented a new strategy to regulate the waste management of landfills, the National Strategy for the Reduction of Biodegradable Municipal Waste Going to Landfills (ENRRUBDA) [42]. Together with the implementation of the second Strategic Plan for Urban Waste (PERSU II) in 2007, the landfill destination started to decrease. Despite this decrease, according to Eurostat, since 1995 the amount of urban waste deposited in Landfills in Portugal (222 kg per capita in 2014) is higher than the EU-average (133 kg per capita in 2014). In the most recent year of data availability (2014), all alternative destinations to landfills in Portugal were below the EU-28 average [34]. In 2015, the Portuguese share of recycled packaging in total produced (57.1\%) was below the EU-28 average (65.7\%). The state of urban waste handling in Portugal indicates the need to apply further efforts in this sector, to bring about closer conformity to EU standards [43] (see Table 5).

Since 1995, the primary energy production of Portugal comes entirely from renewable energies [35]. According to Eurostat, since 2000, Portugal's primary energy consumption has always been below the EU-28 average. In 2016, the EU-28 average was 55.1 Mtoe, and in Portugal was only 21.8 Mtoe [34]. The EU RES Directive (Directive 2009/28/EC on the promotion of the use of energy 
from renewable sources), set the objective of meeting at least $20 \%$ of the EU's final energy consumption with RES, by 2020. Portugal committed itself to a share of renewable sources of $31 \%$ of final energy consumption by then. In 2016, Portugal was the third EU-28 country with the best performance in the inclusion of renewable energies in the electricity sector [44]. In this year, the share of "hydroelectric" and "wind" component in total electricity production in Portugal was $26.1 \%$ and $20.7 \%$, and the EU-28 average was only $10.8 \%$ and $9.3 \%$, respectively. On the other hand, the "photovoltaic" component is still below the EU-28 average. In 2016, the EU-28 average was $3.2 \%$, but in Portugal was only $1.4 \%$ [43] (see Table 5). The energy and carbon intensity of the Portuguese economy, which has been declining since 2005, is starting to approach the EU-28 average. In 2016, the energy intensity of the Portuguese economy was 133 toe/M€'2010, and the EU-28 average was 119 toe/M€'2010. In 2015, the carbon intensity of the Portuguese economy was $0.4 \mathrm{~kg} \mathrm{CO} \mathrm{CO}_{2} \mathrm{e} / € \mathrm{GDP}$, and the EU-28 average was $0.3 \mathrm{~kg} \mathrm{CO}_{2} \mathrm{e} / € \mathrm{GDP}$ [44] (see Table 5).

The discussion above reflects the trend-based evaluation presented in Table 3. The positive evolution of the water, air quality, urban waste, and energy sectors is remarkable. Some of the evaluated indicators were negative (Water Consumption, Air Temperature, Land Use and Land Cover, Forest fires, Surveillance of Protected Areas, and Waste Production) or showed only moderate progress (Classified Areas for Nature and Biodiversity Conservation). In terms of target-based evaluation, Portugal met the targets for population served with water supply systems, GHG emissions, recycling of urban waste, primary energy consumption, and electricity produced from RES. With further effort, it should be possible to attain the targets for population served by wastewater drainage and treatment systems, drinking-water quality, protected area covered by management plan, and waste management (landfill disposal and recycling). More effort is necessary in regard to the indicators that did not meet the targets, such as forest fires, and waste production.

In 1986, by joining the EEC, Portugal began a period of severe reforms and big investments in infrastructures, largely because of the increase of trade ties and the inflow of EEC funds. As a result, a rapid acceleration of Portugal's economic growth followed [45]. This economic growth, and the subsequent economic crisis (2010-2014), influenced the evolution of almost all selected indicators, such as "population served with water supply systems", "population served by wastewater drainage and treatment systems", "GHG emissions", "land use and land cover", and "primary energy production and consumption". Figure 21 highlights the increase of the Portuguese gross domestic product (GDP) and its slowdown during the economic crisis 2010-2014, which influenced the evolution of the indicators for GHG emissions and waste production. The interruption of industrial activities in Portugal contributed to GHG emissions decrease, and the fall in net income and consumer spending contributed to the reduction of goods consumed, and therefore to the decrease of urban waste production. 


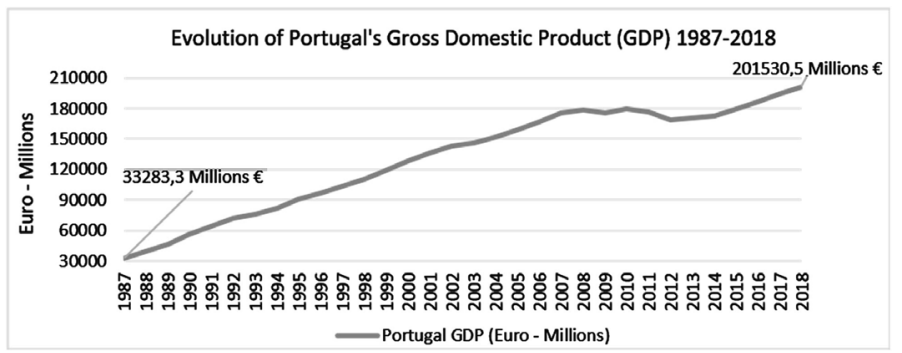

Figure 21. Evolution of portugal's Gross Domestic Product (GDP), between 1987 and 2018. Note: GDP according to European System of Accounts 2010. Source: [47].

According to García-Álvarez and Moreno [46], Sweden, Austria, Denmark, Italy and Germany are the EU-28 countries with the best scores in environmental performance assessment. These countries have been characterized by the deployment of suitable policies related to biodiversity, water, waste, energy, transport, and sustainable consumption, production and efficient use of resources. In terms of environmental performance assessment of EU-28 members, Portugal is in an intermediate position (position 14), right behind countries such as Finland, France, and the United Kingdom. According to this study, Portugal is a success in terms of GHG emissions and renewable energies. This paper also notes that Portugal requires additional measures to promote efficient energy consumption in the transport sector as well as to develop a more efficient use of resources by increasing its resource productivity [46]. In the last 30 years, Portugal has shown a great evolution in environmental sustainability, and by pursuing the development of ambitious environmental policies, Portugal can achieve the levels of the top ranking countries.

\section{Conclusions}

Over the last decades, the EU has developed a large range of environmental policies and regulations. The accession of Portugal to the Treaty of Rome and thus membership of the European Economic Community in 1986 brought several benefits to the country. The support of EU funds and the development of environmental policies in Portugal, driven by community commitments, have been essential for Portugal's development. Portugal's standards have become closer to those of the EU and in several indicators even exceeded those requirements, for example Houses served with water supply systems, and proportion of land area covered by Natura 2000 Network.

In this paper, indicators from the Portuguese "Sustainable Development Indicators System" have been selected to characterize the evolution of environmental sustainability of Portugal, in the last 30 years. The 18 selected indicators have been grouped into 7 sectors (Water, Air Quality, Land Use, Nature and Biodiversity Conservation, Environmental Risks, Urban Waste, and Energy). For each selected indicator, the "Traffic Light System" approach was applied in order to measure trend-based and target-based progress of the indicators. The selected 
indicators that could evaluate the goals of the 2030 Agenda for Sustainable Development have been identified.

The results suggest Portugal's environmental sustainability evolved remarkably in the last 30 years. The water, air quality, urban waste, and energy sectors showed good results in most indicators. But land use, nature and biodiversity conservation, and environmental risks sector were not so positive. In terms of target-based evaluation, Portugal met five out of eleven targets, with successes relating to population served with water supply systems, GHG emissions, recycling and valorization of urban waste. For the indicators that did not meet the targets, such as forest fires, and waste production, more efforts are necessary. In terms of the 2030 Agenda for Sustainable Development, the performance of the SDGs $6,7,11,12$, and 15 in Portugal can be evaluated since 1987, using 11 of the 18 selected indicators. In the context of the EU, Portugal achieved better results than the EU-28 average in 11 indicators related to water supply systems, wastewater drainage and treatment, coastal and transitional bathing waters quality, GHG emissions, air pollution, Natura 2000 network, waste production, primary energy consumption, and renewable energies. Portugal still needs to pursue continuous development of ambitious environmental policies, in order to achieve the levels of the top countries, but the general trend of improvement is significant. In our common progress towards sustainable development, it is clear that sound public environmental policies do have dramatic effects on the quality of life.

\section{Acknowledgements}

The authors express their deep gratitude to the National Council for Environment and Sustainable Development (CNADS) for their institutional support and providing access to all the necessary information. Special thanks go to the Executive Secretary, Dr. Adília Lopes, who played a key role in the joint supervision of the original work of the master's thesis on which this article was based.

\section{Conflicts of Interest}

The authors declare no conflicts of interest regarding the publication of this paper.

\section{References}

[1] World Commission on Environment and Development (1987) Report of the World Commission on Environment and Development: Our Common Future. WCED, Washington DC.

[2] United Nations, UN (1992) Agenda 21. United Nations Conference on Environment \& Development. UN, Rio de Janeiro.

[3] Organization for the Economic Cooperation and Development, OECD (1993) Organization for the Economic Cooperation and Development Core Set of Indicators for Environmental Performance Reviews. Organization for the Economic Cooperation and Development Environmental Directorate Monographs 83, Paris. 
[4] European Environmental Agency, EEA (1995) Europe's Environment: The Dobris Assessment. EEA, Copenhagen.

[5] Gabrielsen, P. and Bosch, P. (2003) Environmental Indicators: Typology and Use in Reporting. Internal Working Paper, Copenhagen.

[6] Tscherning, K., Helming, K., Krippner, B., Sieber, S. and Paloma, S. (2012) Does Research Applying the DPSIR Framework Support Decision Making? Land Use Policy, 29, 102-110. https://doi.org/10.1016/j.landusepol.2011.05.009

[7] Gari, S., Newton, A. and Icely, J. (2015) A Review of the Application and Evolution of the DPSIR Framework with an Emphasis on Coastal Social-Ecological Systems. Ocean and Coastal Management, 103, 63-77. https://doi.org/10.1016/j.ocecoaman.2014.11.013

[8] European Environmental Agency, EEA (2005) EEA Core Set of Indicators-Guide. Technical Report 1/2005. EEA, Luxembourg.

[9] European Environmental Agency, EEA (2014) Digest of EEA Indicators 2014. Technical Report 8/2014. EEA, Copenhagen.

[10] Smeets, E. and Weterings, R. (1999) Environmental Indicators: Typology and Overview. Technical Report 25. EEA, Copenhagen.

[11] Eurostat (2017) Sustainable Development in the European Union-Monitoring Report on Progress towards the SGDs in an European Union Context. Publications Office of the European Union, Luxembourg.

[12] United Nations Regional Information Centre, UNRIC (2016) Guia Sobre Desenvolvimento Sustentável: 17 Objetivos para Transformar o Nosso Mundo. Centro de Informação Regional das Nações Unidas para a Europa Ocidental, Lisbon.

[13] Eurostat (2017) European Union SDG Indicator Set. European Commission, Luxembourg.

[14] National Statistics Institute , INE (2017) Objetivos de Desenvolvimento Sustentável. Instituto Nacional de Estatística, Lisbon.

[15] Portuguese Environment Agency, APA (2007) Sustainable Development Indicators System-SIDS Portugal. Agência Portuguesa do Ambiente, Lisbon.

[16] Maas, R., Kruitwagen, S. and Gerwen, O. (2012) Environmental Policy Evaluation: Experiences in Netherlands. Environmental Development, 1, 67-78.

https://doi.org/10.1016/j.envdev.2011.12.006

[17] Cook, D., Saviolidis, N., Davíósdóttir, B. and Jóohannsdóttir, L. (2017) Measuring Countries Sustainability Performance-The Development of a Nation-Specific Indicator Set. Ecological Indicators, 74, 463-478. https://doi.org/10.1016/j.ecolind.2016.12.009

[18] Ministry of Environment, Territorial Planning and Regional Development, MAOTDR (2007) Plano Estratégico para os Resíduos Sólidos Urbanos 2007-2016 (PERSU II). Ministério do Ambiente, do Ordenamento do Território e do Desenvolvimento Regional, Lisbon.

[19] Ministry of Environment, Territorial Planning and Regional Development, MAOTDR (2007) Plano Estratégico de Abastecimento de Água e de Saneamento de Águas Residuais 2007-2013. Ministério do Ambiente, do Ordenamento do Território e do Desenvolvimento Regional, Lisbon.

[20] Frade, J.V. (2015) PENSAAR 2020-Uma nova Estratégia para o Setor de Abastecimento de Água e Saneamento de Águas Residuais Volume II. Ministério do Ambiente, Ordenamento do Território e Energia, Lisbon. 
[21] Portuguese Environment Agency, APA (2006) National Strategy for Sustainable Development 2015. Agência Portuguesa do Ambiente, Lisbon.

[22] United Nations, UN (2015) Transforming Our World: The 2030 Agenda for Sustainable Development. UN, New York.

[23] United Nations, UN (2019) Sustainable Development Goals Knowledge Platform. https://sustainabledevelopment.un.org/

[24] European Commission, EC (2019) Environment Action Programme to 2020. http://www.ec.europa.eu/environment/action-programme/

[25] Popeangã, V. (2013) Environmental Action Programmes in the European Union Evolution and Specific. Annals of the Constant in Brancusi III, 3, 24-33.

[26] European Commission, EC (1993) Towards Sustainability-Fifth Environmental Action Programme. European Commission, European Union.

[27] Agency for Development and Cohesion, I.P. (2018) Agência para o Desenvolvimento e Coesão. http://www.adcoesao.pt/

[28] Ministry of Agriculture, Sea, Environment and Spatial Planning, MAMAOT (2012) Programa Nacional para o Uso Eficiente da Água-Implementação 2012-2020. Ministério da Agricultura, do Mar, do Ambiente e do Ordenamento do Território, Lisbon.

[29] Water and Waste Services Regulation Authority, ERSAR (2010) Relatório Anual dos Serviços de Águas e Resíduos em Portugal (2009)-Volume 1-Caraterização do setor de águas e resíduos. Entidade Reguladora dos Serviços de Águas e Resíduos, Lisbon.

[30] Water and Waste Services Regulation Authority, ERSAR (2017) Relatório anual dos Serviços de Águas e Resíduos em Portugal (2017)-Volume 1-Caraterização geral do setor. Entidade Reguladora dos Serviços de Águas e Resíduos, Lisbon.

[31] Portuguese Environment Agency, APA (2018) State of the Environment Portal-Portugal. https://rea.apambiente.pt/

[32] Intergovernmental Panel on Climate Change, IPCC (2014) Climate Change 2014: Synthesis Report. Contribution of Working Groups I, II and III to the Fifth Assessment Report of the Intergovernmental Panel on Climate Change. Geneva.

[33] European Commission, EC (2019) European Commission-Environment. http://www.ec.europa.eu/environment/air/quality/existing leg.htm

[34] Eurostat (2017) European Union Sustainable Development Strategy (EU SDS). http://ec.europa.eu/eurostat/web/sdi/eu-sds

[35] Environment Institute, IA (2006) State of the Environment Report 2005. Instituto do Ambiente, Lisbon.

[36] General Directorate for Territorial Development, DGT (2014) Uso e Ocupação do Solo em Portugal Continental: Avaliação e Cenários Futuros-Projeto LANDYN. Direção-Geral do Território, Lisbon.

[37] Institute for Nature Conservation and Forestry, ICNF (2018) Instituto da Conservação da Natureza e das Florestas: Convenção sobre a Diversidade Biológica. http://www2.icnf.pt/portal/pn/biodiversidade/ei/cbd

[38] European Commission, EC (2018) European Commission-Natura 2000 Barometer.

http://www.ec.europa.eu/environment/nature/natura2000/barometer/index en.htm

[39] National Council of the Environment and Sustainable Development, CNADS (2016) Reflexão sobre a Gestão da Rede Nacional de Áreas Protegidas. Conselho 
Nacional do Ambiente e Desenvolvimento Sustentavel, Lisbon.

[40] European Commission, EC (2018) Forest Fires in Europe, Middle East and North Africa 2017. Ispra: Joint Research Centre of European Commission, Italy.

[41] World Wildlife Fund, WWF (2017) Incêndios Rurais em Portugal: até quando deixaremos a paisagem arder?-Relatório Técnico. World Wildlife Fund Portugal, Lisbon.

[42] Portuguese Environment Agency, APA (2014) State of the Environment Report 2014. Agência Portuguesa do Ambiente, Lisbon.

[43] PORDATA (2017) PORDATA Base de Dados Portugal Contemporâneo. https://www.pordata.pt/DB/Portugal/Ambiente+de+Consulta/Tabela

[44] Portuguese Environment Agency, APA (2017) State of the Environment Report 2017. Agência Portuguesa do Ambiente, Lisbon.

[45] European Commission, EC (2017) The European Union Environmental Implementation Review Country Report-Portugal. Directorate-General for Environment-European Commission, Brussels.

[46] García-Álvarez, M.T. and Moreno, B. (2018) Environmental Performance Assessment in the EU: A Challenge for the Sustainability. Journal of Cleaner Production, 205, 266-280.

[47] Eurostat (2019) European Comission Eurostat-European Statistics. https://www.ec.europa.eu/eurostat/web/national-accounts/data/main-tables 